\title{
Characteristics, Constraints and Perspectives of the Fish Farming in Burundi
}

\author{
Charles Niyonkuru ${ }^{1}$, Emile Nibona ${ }^{1}$ and Jacques Moreau ${ }^{2}$ \\ 1. Department of Biology, Institute of Applied Pedagogy, University of Burundi, Bujumbura 5223, Burundi \\ 2. Department of Aquatic Environment, Institute of National Polytechnique/Ecole Nationale Supérieure Agronomique Toulouse, \\ Auzeville Tolosane 31326, France
}

\begin{abstract}
The fish farming was introduced in Burundi in about 1950s. Actually, several fish ponds were abandoned and many others were still unproductive. This study aims to present current state and perspectives of the fish farming for its real contribution to the socio-economic development. The results presented are compilation of physical and chemical parameters series measured in fish ponds and inquiries led in 2010-2014 to the fish farmers in seven provinces (40\% of the total area of the country). Weak values of some physical and chemical parameters showed that the majority of ponds are badly maintained. Thus, the dissolved oxygen values varied between $0.2 \mathrm{mg} / \mathrm{L}$ and $3.5 \mathrm{mg} / \mathrm{L}$. The high relinquishment rate of the fish farming (between $40 \%$ and $67 \%$ according to the provinces) could be explained by many constraints: no centers of fish farming breeding for various fish species and no production center of complete foods with local sub-products. About $75 \%$ of fish famers confirmed that they have never benefited framing in fish farming. In spite of the diverse constraints, Burundi has a dense rivers system with favorable physical and chemical parameters and many appropriate sites for the fish farming. Thus, the main suggestions concern the sector reorganization.
\end{abstract}

Key words: Fish farming, oreochromis niloticus, Burundi.

\section{Introduction}

Burundi covers an area of $27,834 \mathrm{~km}^{2}$ with $2,700 \mathrm{~km}^{2}$ of lakes and 23,500 $\mathrm{km}^{2}$ of potential agricultural lands [1]. Close to $70 \%$ of the population live below the poverty line (less than one USD per day and per capita) and $85 \%$ of household cope daily to food insecurity [2]. The fish consumed comes essentially from the lake of Tanganyika and lakes of the north of Burundi that are not able to produce sufficient quantities of fishes for all Burundian households. Fish's quantities caught in these lakes and in some rivers are insufficient to satisfy the constantly increasing population (population: 8,060,000 habitants, mean density: 310 $\mathrm{hab} / \mathrm{km}^{2}$ and average demographic growth rate: $2.4 \%$ ) [3]. Only some urban populations and those near of these lakes can benefit from these fishes. In these lakes, the increase of the fishing effort in order to

Corresponding author: Charles Niyonkuru, Ph.D., main research fields: environment and fisheries management. E-mail: cniyon@yahoo.fr. intensify production results in the use of prohibited fishing gears. As consequences, one attends the biodiversity loss and stocks depletion. Therefore, it is clear that the fish farming could be a way to preserve the country piscatorial stocks, cover the population needs and correct the observed regional disparities in the fish consumption.

The fish farming has been introduced in Burundi towards years 1950 and about 352 ponds had been already finished in 1960 [4]. The main station of fish farming built was located in Karuzi province (in center of the country) with 23 ponds of 0.5 ha and 50 nursery ponds of 1.30 ha. The fish farming raise activities began in 1984 with the arrival of the Peace Corps Volunteers/USAID and programs initiated by F.A.O.. In all initiatives to promote fish farming, one advocated family-type farms in ponds of $200 \mathrm{~m}^{2}$ with compost feeding. In 1991, it counted close to 4,000 individual ponds [5]. Unfortunately, the technical framing did not follow this expansion. Ponds were 
poorly managed and proved unproductive (10 $\mathrm{kg} / \mathrm{are} /$ year). For remedying to that situation, a national project on fish farming was developed from 1991 to 1994 . That project permitted the training of 54 coaches and supported 225 pilot fish farmers. It should also contribute to increase the production and promote the multiplication of didactic material. At last, it should also contribute to the improvement of fish farming techniques such as pond construction, use of rice bran for fish feeding and practice of associated raisings. In 1999, there were nearly 2,000 fish farmers throughout Burundi exploiting 2,500 ponds built on 60 hectares with annual production estimated at 120 tons.

The government of Burundi in its National Agricultural Strategy (2008-2015) had considered the promotion of commercial fish farming whose main objective is to accelerate the growth of fish farming through increasing fish farm areas, diet and introduction powerful species and also through greater efficiency of investments.

Thus, the dense river network (Fig. 1), the government willingness, the various efforts of Burundian government and its partners and population didn't permit the efficient development of the fish farming. The current report is that the rural fish farming didn't succeed again in filling hiatuses bound to the food insecurity of the Burundian population. Observations on field reveal that several fish ponds have been abandoned and many others remain unproductive. The population pressure on lakes and rivers in search of fish are still very high.

As objectives, this study aims to:

- Present characteristics and identify constraints of fish farming in Burundi;

- Clear potentialities and propose solutions for an efficient take-off fish farming in Burundi.

\section{Materials and Methods}

The results presented here are a compilation of studies conducted between 2010 and 2014 in 7 provinces (Bujumbura, Bubanza, Cibitoke, Kirundo, Makamba, Muramvya and Rutana (Fig. 1)) of 16 provinces that count the country. The studied provinces represent close to $40 \%$ of the total land area.

Data collection has been made every time in two phases namely:

- The physical and chemical parameters sampling and ponds characterization (dimensions, installation locations, state and water availability etc.);

- The investigation close to individual fish farmers or in associations.

Table 1 showed that a total of 87 ponds and 151 fish farmers had been the subject of physic-chemical parameters analysis and investigation in all 21 municipalities belonging to the 7 provinces respectively.

In each fishpond, the different physical and chemical parameters measured and the materials used are:

- Depth and water transparency in centimeter with Secchi disk;

- Water pH, ambient and water temperature in ${ }^{\circ} \mathrm{C}$ and TDS (Total Dissolved Solid) in $\mathrm{mg} / \mathrm{L}$ by the pH-meter multi-function HANNA (HI-9812-5);

- Dissolved oxygen (mg/L) with the Oxymeter HANNA (HI 9142).

\section{Results and Discussion}

\subsection{Physical and Chemical Characteristics of the Ponds}

The extreme values of the measured physical-chemical parameters are presented in Table 2.

The analysis of this table shows that:

- The ambient and water temperature of ponds varied between $17.5{ }^{\circ} \mathrm{C}$ and $28{ }^{\circ} \mathrm{C}$ according to provinces. The water temperature is a key criterion in the choice of species [6]. A temperature varying between $20^{\circ} \mathrm{C}$ and $30{ }^{\circ} \mathrm{C}$ is generally good for fish farming. In some areas of Bujumbura and Muramvya, provinces in altitude between $1,500 \mathrm{~m}$ and 2,500 $\mathrm{m}$ and temperatures below $17^{\circ} \mathrm{C}$ are recorded following the period of the year. These temperatures do not 


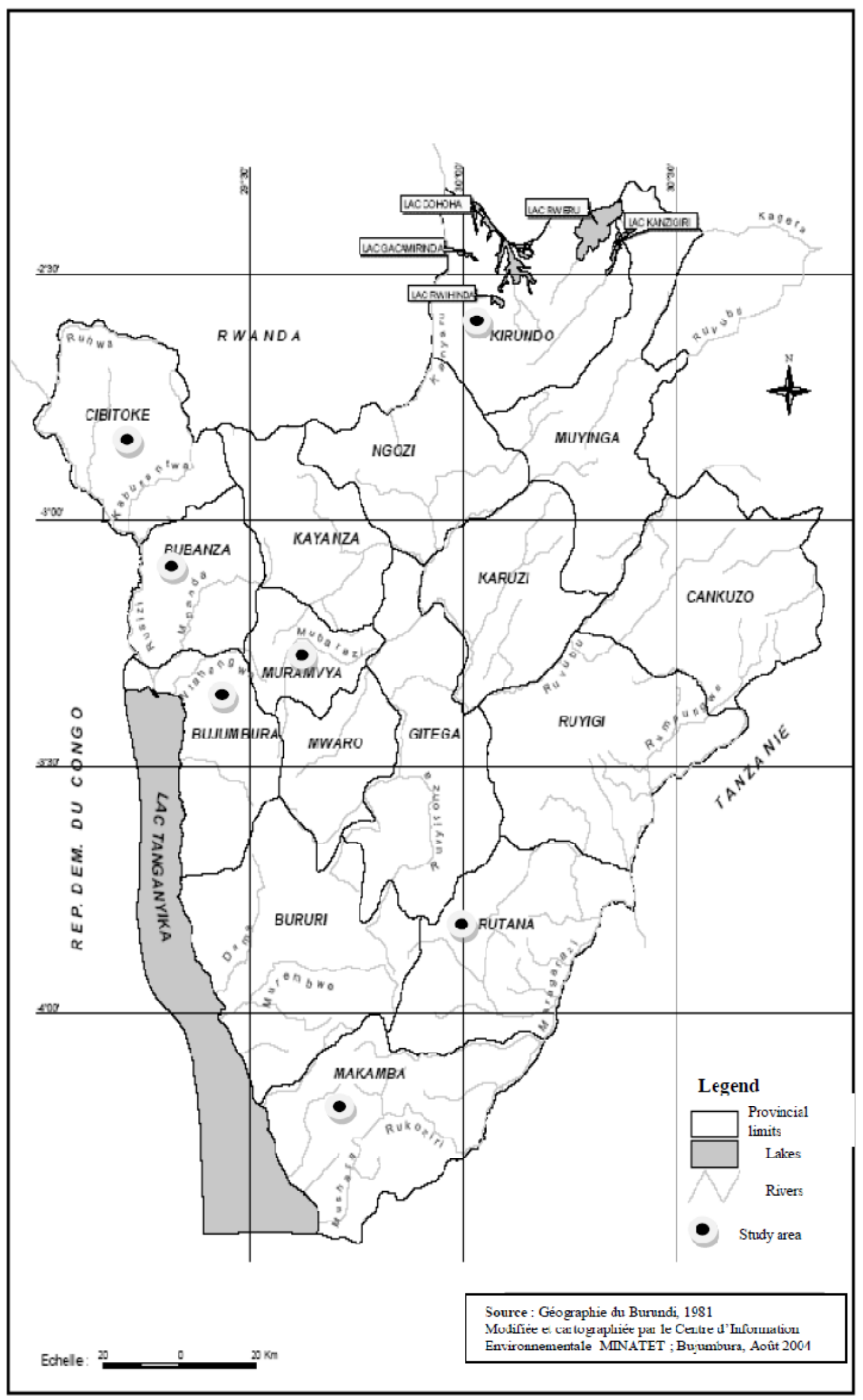

Fig. 1 Map of Burundi showing the study area. 
Table 1 Distribution of sampled fish ponds and fish farmers investigated in the study area.

\begin{tabular}{|c|c|c|c|}
\hline Provinces & Municipalities targeted for survey & Number of ponds sampled & Number of fish farmers investigated \\
\hline \multirow{3}{*}{ Bubanza } & Musigati & 21 & 21 \\
\hline & Bubanza & 2 & 5 \\
\hline & Gihanga & 5 & 5 \\
\hline \multirow{3}{*}{ Bujumbura } & Mubimbi & 4 & 4 \\
\hline & Mutimbuzi & 4 & 4 \\
\hline & Muhuta & 4 & 4 \\
\hline \multirow{3}{*}{ Cibitoke } & Mugina & 5 & 10 \\
\hline & Murwi & 2 & 10 \\
\hline & Rugombo & 4 & 15 \\
\hline \multirow{3}{*}{ Kirundo } & Kirundo & 5 & 5 \\
\hline & Vumbi & 2 & 2 \\
\hline & Busoni & 2 & 2 \\
\hline \multirow{4}{*}{ Makamba } & Kayogoro & 4 & 7 \\
\hline & Makamba & 5 & 13 \\
\hline & Nyanza-Lac & 2 & 10 \\
\hline & Vugizo & 2 & 4 \\
\hline \multirow{3}{*}{ Muramvya } & Muramvya & 3 & 6 \\
\hline & Mbuye & 1 & 6 \\
\hline & Rutegama & 3 & 5 \\
\hline \multirow{2}{*}{ Rutana } & Rutana & 3 & 6 \\
\hline & Minga-Kayove & 2 & 7 \\
\hline 7 & 21 & 85 & 151 \\
\hline
\end{tabular}

Table 2 Summary of the physicochemical parameters in the study area.

\begin{tabular}{llllllll}
\hline Parameters & Bujumbura & Bubanza & Cibitoke & Makamba & Muramvya & Rutana & Kirundo \\
\hline Ambient temperature $\left({ }^{\circ} \mathrm{C}\right)$ & $(18.5,25)$ & $(19.5,29)$ & $(24,28.5)$ & $(19.5,26)$ & $(18,23)$ & $(17.5,28)$ & $(20.3,21.3)$ \\
Water temperature $\left({ }^{\circ} \mathrm{C}\right)$ & $(18,24,5)$ & $(19,28)$ & $(20,25.5)$ & $(19.5,25)$ & $(18,23)$ & $(18,26)$ & $(21,22)$ \\
Water pH & $(7.1,7.6)$ & $(6.1,7.5)$ & $(6.9,8.2)$ & $(6.8,8)$ & $(6.2,7.5)$ & $(6.5,7.5)$ & $(6.8,7)$ \\
Dissolved oxygen $(\mathrm{mg} / \mathrm{L})$ & $(1.55,1.75)$ & $(0.4,4.5)$ & $(1.1,4.5)$ & $(3,5)$ & $(0.5,3.6)$ & $(2.5,5.5)$ & $(0.56,2.4)$ \\
Conductivity $(\mu \mathrm{S} / \mathrm{cm})$ & $(100,127.5)$ & $(13,40)$ & $(75,110)$ & $(10,95)$ & $(60,110)$ & $(10,90)$ & $(10,273.7)$ \\
TDS $(\mathrm{mg} / \mathrm{L})$ & $(40,60)$ & $(10,20)$ & $(30,80)$ & $(20,75)$ & $(10,60)$ & $(5,40)$ & $(50,136.7)$ \\
Water depth $(\mathrm{cm})$ & $(70,100)$ & $(50,100)$ & $(40,80)$ & $(70,120)$ & $(40,100)$ & $(60,70)$ & $(30.6,65)$ \\
Water transparency $(\mathrm{cm})$ & $(28.5,38)$ & $(10,40)$ & $(7,25)$ & $(15,40)$ & $(5,30)$ & $(20,35)$ & $(11.3,16.3)$ \\
Area ponds (are) & $(1.58,7.6)$ & $(0.4,4)$ & $(0.6,3.4)$ & $(4,5)$ & $(0.4,10.5)$ & $(1.5,5.2)$ & $(5,12.3)$ \\
\hline
\end{tabular}

allow optimal growth of tilapia raised in these localities. In Rutana province, fishponds were also implanted in hills where temperatures below or equal to $17^{\circ} \mathrm{C}$ are often recorded;

- The water $\mathrm{pH}$ values ranged from 6.1 to 8.2 according to the ponds. The fish water must have a certain degree of acidity indicated by the water $\mathrm{pH}$ value ranged between 6.7 and 8.6 [6]. In Bubanza, Muramvya and Kirundo provinces, $\mathrm{pH}$ values below
6.7 were recorded;

- The weak dissolved oxygen values were recorded for most ponds. Indeed, according to F.A.O. [7], the needs of dissolved oxygen for tilapia (genus mainly bred in the study area) vary according to the stages of life: the minimum value is $2 \mathrm{mg} / \mathrm{L}$ for adults while the preferred value is $4 \mathrm{mg} / \mathrm{L}$. The inferior extreme values recorded in ponds of 5 provinces on the 7 studied were lower to $2 \mathrm{mg} / \mathrm{L}$. In Bujumbura, Muramvya and 
Kirundo provinces, no dissolved oxygen value equal to $4 \mathrm{mg} / \mathrm{L}$ (preferred value for tilapia) were recorded. Therefore, the authors can retain that ponds are badly maintained;

- The water conductivity of ponds varied from 10 $\mu \mathrm{S} / \mathrm{cm}$ to $273.7 \mu \mathrm{S} / \mathrm{cm}$ according to the ponds. Values found during this study are in some cases different from those of Moreau [8]. In his study on development possibilities of intensive fish farming in Burundi, he confirmed that the Burundian water ponds, lakes and rivers have electrical conductivity varying between $40 \mu \mathrm{S} / \mathrm{cm}$ and $60 \mu \mathrm{S} / \mathrm{cm}$. According to Vivier [9], fishes support an electrical conductivity which does not exceed the maximum threshold $70 \mu \mathrm{S} / \mathrm{cm}$. It is only in the Bubanza province where the two extreme values recorded for all ponds were lower than $70 \mu \mathrm{S} / \mathrm{cm}$. According to him, in the all ponds where conductivity values recorded were greater than that value, fishes could have problems;

- The upper extreme TDS values recorded in the majority of cases were low (less than or equal to 80 $\mathrm{mg} / \mathrm{L}$ ) except in Kirundo province where higher extreme values of $136.7 \mathrm{mg} / \mathrm{L}$ were recorded. Total suspended solids in the water of a pond that is sustainable for the fish must not exceed the maximum threshold of $75 \mathrm{mg} / \mathrm{L}[9,10]$. So, it could globally be retained that TDS didn't constitute a limiting factor for the growth of fishes in the study area;

- The minimum water depth of the ponds on the shallow side is between $50 \mathrm{~cm}$ and $100 \mathrm{~cm}$ on all ponds of Bubanza, Bujumbura, Makamba and Rutana provinces. For other ponds like those of Cibitoke, Muramvya and Kirundo provinces, the recorded extreme values were $(40,80),(40,100)$ and $(30.6,65)$ respectively. This is usually ponds where it is difficult to find the shallow and deeper sides because the depth is almost the same everywhere. The water depth is usually between $0.50 \mathrm{~m}$ and $1 \mathrm{~m}$ on the shallow side and can reach $1.5 \mathrm{~m}$ or $2 \mathrm{~m}$ on the side of the drain point [6]. These results showed that this is not the case for many ponds of the study area;
- Except ponds of Bujumbura province and in some cases of Rutana province, the lower extremes values of transparency are generally less than $25 \mathrm{~cm}$. Otherwise, Assiah et al. [6] recommend a water transparency situated between $25 \mathrm{~cm}$ and $30 \mathrm{~cm}$ for a good production of algae and higher fish production;

- The ponds area varied from 0.4 ares to 12.3 ares according to cases. For most provinces, there are ponds whose area value is lower or equal to one are. In some provinces like Bubanza and Cibitoke, measured upper extreme values were less than or equal to 4 ares. The recommended ideal average area for fish is about 4 ares [11]. The average area recommended for intensive fish farming is about 5 ares $[9,11]$. As regard to the obtained results and considering observations of these authors, they may wonder if some of the ponds were built for intensive fish or just for fish production for own consumption.

\subsection{Fish Species and Farming Methods}

Throughout the study area, Oreochrimis niloticus remains the main rearing fish species. In some cases, it is possible to find catfish as Clarias gariepinus introduced accidentally during floods or voluntarily by fish farmers. In fish ponds located in plains like Cibitoke and Bubanza provinces, the National Center for Aquaculture and Artisanal Fishing Development (CNDAPA, in French acronym) produces in its experimentation and nursery center some fingerlings of Clarias gariepinus, but these still in insufficient quantities and inaccessible for many fish farmers. Even for $O$. niloticus, this single center cannot produce enough fingerlings to fish farmers all across the country. Therefore, only few fish farmers around the centre arrive to source good quality fingerlings. In the majority of cases ( $100 \%$ of cases for fish farmers in provinces other than Bujumbura), fish farmers buy their fry from other fish farmers. Even for the nearest localities of the center, means of transport was still limited. Indeed, only 31\% of functional ponds in Bujumbura province were stocked with fingerlings 
distributed by CNDAPA. In Kirundo province (located in the extreme north of the country) $64.2 \%$ of the ponds were stocked with fingerlings from Cohoha Lake or other ancient ponds from nearby localities in the same province. Regarding husbandry practices, the hetero-sex farming is practiced by $100 \%$ of fish farmers in all provinces studied except Bujumbura province where separate sex for breeding is practiced by $16.6 \%$ of the fish farmers investigated. Thus, it is difficult to get the big size fishes that can increase the fish farmers' income in those conditions.

\subsection{Food Fish and Frequency Distribution}

Across the country, there is no center for the production of fish's compound foods. Foods distributed to fish in more than $95 \%$ of cases are constituted agricultural by-products (sweet potato or papaya leaves, banana trunks, cassava peelings, rice or maize bran etc.) manure and dead animals. Some of these products are directly consumed by fish and other decomposes to serve fertilization. Rice and maize bran or meals are rarely used by fish farmers. In case of feeding with rice or maize bran, distribution frequency is twice a day or 1-3 times a week depending on the means of fish farmers. In some cases, nothing is distributed to the fish. This is the case of the Bujumbura province where $40.83 \%$ of investigated fish farmers confirmed that no food is thrown in their ponds.

\subsection{Abandon Rates of Fish Ponds and Motives}

Table 3 shows the numbers of functional and non-functional fish ponds and percentages of abandoned fishponds. On the whole, nearly $44.5 \%$ of the ponds were already abandoned. It is in Bujumbura and Cibitoke provinces where high numbers of abandoned ponds were recorded (1,254 and 151 respectively). The only province where there are still many functional ponds recorded (or 1,053 in total) with low abandon rate (3.9\%) is Makamba located in the south of the country. In this province, fish farming knew an impetus with the advent of an ex-fighter association for the auto development, ADECA in acronym, which had started its activities in 2011 with the recruitment of members per municipality. In 2013, near 8,199 fish farmers in associations could be registered throughout the province. It was also possible to get an annual production up to 3 tons in a total of 37 ponds with an average area of 4 ares each.

Table 3 Abandon rates of fish ponds and motives.

\begin{tabular}{lllll}
\hline Provinces & Number of functional ponds & Number of non-functional ponds & Abandon rates (\%) & Year \\
\hline Bujumbura & 45 & 1,254 & 96.5 & 2010 \\
Bubanza & 44 & 6 & 12 & 2010 \\
Bururi & 5 & 6 & 55.5 & $2006^{*}$ \\
Cankunzo & 29 & 4 & 12.1 & $2006^{*}$ \\
Cibitoke & 227 & 151 & 39.9 & 2013 \\
Karusi & 74 & - & - & $2006^{*}$ \\
Kayanza & 33 & 6 & 15.4 & $2006^{*}$ \\
Kirundo & 179 & - & - & 2010 \\
Makamba & 1,053 & 42 & 5.9 & 2014 \\
Muramvya & 32 & 38 & - & 2010 \\
Muyinga & 83 & - & - & $2006^{*}$ \\
Mwaro & 31 & - & - & $2006^{*}$ \\
Ngozi & 52 & - & 47.6 & $2006^{*}$ \\
Rutana & 22 & 20 & 48.7 & 2010 \\
Ruyigi & 39 & 37 & 44.5 & $2006^{*}$ \\
Total & 1,948 & 1,564 & & \\
\hline
\end{tabular}

* Data from the provincial monographs of Burundi. 
Among the main reasons of abandon given by fish farmers surveyed, it could be mentioned:

- The low profitability of fish farming: According to the provinces, $60 \%-90 \%$ of fish farmers showed that fish farming is not profitable compared to other activities such as rice or oil palm cultures or others. In Bujumbura province, production by exploitation of a pond of 4 ares is sometimes less than $20 \mathrm{~kg}$. Close to $60 \%$ of fish farmers investigated show that the low production is directly shared among members of the community or family. In Makamba province, the annual average yield of a fish pond of 4 ares is about 25-30 kg;

- The lack of good quality and diversified fingerlings: As mentioned above, the only CNDAPA with its experimentation and nursery center was still enable to provide enough fingerlings to all fish farmers across the country;

- The lack of financial support: Fish farmers surveyed indicated unanimously that the digging of modern ponds, the buying of other equipment (for digging and for fisheries control (balance, sorting table and various packaging etc.)) cost so expensive that they are unable to get them by themselves. It should be noted here that the majority of fish ponds had been dug with the financial support of partners and NGOs. The various funds have often closed before the fish farmers obtain enough own income to take themselves in charge. The Government of Burundi has never arrived to institute a supporting fund for fish farming promotion to support fish farmers at the end of external funding;

- The insufficient technical supervision. Between $75 \%$ and $95 \%$ of fish farmers investigated (according to the provinces) are convinced that they are amateurs in this field and they do not have any adequate technical supervision. The consequences of the lack of supervision in the study area are reflected in particular by setting load groping (more than 2 fingerlings $/ \mathrm{m}^{2}$ recommended for tilapia [12]), irregular exploitations of fish ponds varying from one to three times a year and also sometimes in disorder;

- Smallness of arable land: Some people consider that for the same land area, rice cultivation is more profitable than fish farming, so, some fish ponds were transformed in rice paddies. Indeed, $80 \%$ of fish farmers surveyed in Cibitoke province have confirmed that fish farming remains an unprofitable business. For them, a land with an area of 5 ares can make an average annual income of about 2,000 USD if rice is planted there which is a sum that cannot be obtained by practicing fish farming.

\subsection{Organizational Mode and Effectiveness}

Organizational dominant mode in fish farming in Burundi is one of the groupings associations. Table 4 shows that about 105 associations whose importance varies across provinces were recorded during the study. The highest numbers of associations were found in Makamba, Kirundo and Cibitoke provinces with 34, 26 and 20 associations respectively. According to the Ministry of Agriculture and Livestock, productions come mainly from fish ponds constructed by groups and associations. The number of fish farmers associations throughout the national territory is about 150 . The average production remains low (200-500 kg/ha/year or 2-3 kg per are) [1].

During this study, it revealed that the highest numbers of abandoned ponds or resignation of members are especially frequent in the associations. Some farmers grouped into associations argue that situation is due to the lack of organization among members. It is often about the opportunistic associations usually formed when there is announcement of funding and dislocated at the end of projects. This is usually associations with high numbers of members (difficult to manage) or associations often without statutes or with poorly developed statutes and therefore, ephemeral. In Makamba province, for example, it was found that a total of 8,199 fish farmers were grouped in associations around 1,053 ponds. The Table 5 shows that in some municipalities, the number of fish 
Table 4 Number of fish farmers associations in the study area.

\begin{tabular}{lc}
\hline Provinces & Number of associations \\
\hline Bubanza & 7 \\
Bujumbura & 8 \\
Cibitoke & 20 \\
Kirundo & 26 \\
Makamba & 34 \\
Muramvya & 6 \\
Rutana & 4 \\
Total & 105 \\
\hline
\end{tabular}

Table 5 Number of fish farmers in associations in the different municipalities of Makamba province.

\begin{tabular}{lcccc}
\hline Municipalities & $\begin{array}{c}\text { Number of functional } \\
\text { fish ponds }\end{array}$ & Area (ares) & Number of fish farmers & $\begin{array}{l}\text { Average number of fish } \\
\text { farmers/ponds }\end{array}$ \\
\hline Kayogoro & 43 & 91.7 & 996 & 23 \\
Makamba & 80 & 321.2 & 1,584 & 20 \\
Mabanda & 43 & 169.7 & 727 & 17 \\
Kibago & 31 & 95 & 625 & 20 \\
Nyanza-Lac & 821 & 3,374 & 3,682 & 4 \\
Vugizo & 35 & 91.5 & 585 & 17 \\
Total & 1,053 & $4,143.1$ & 8,199 & 8 \\
\hline
\end{tabular}

farmers reached 23 per fish pond as in the Kayogoro municipality. The lower effective (4 fish farmers/are) were observed in the Nyanza-lac municipality.

The current report is that fish ponds belonging to individuals are best managed sustainably. Thus, for example, in Bujumbura, it was also revealed that individual ponds are most represented (67\%) than collective ponds (33\%).

\subsection{Fish Farming Typologies in Burundi}

In view of the above characteristics presented on fish farming in Burundi, it could be retained that it is a semi-intensive type according to intensification criteria generally used (extensive fish farming, semi-intensive and intensive etc.). In the light of case studies of development operations implemented in Africa over the past thirty years, four major types of fish farming based on development criteria have been identified [12]. These are: (i) fish farming to consumption; (ii) artisanal fish farming "small" market production; (iii) fish farm of type "chain" or "segmented" and (iv) industrial fish farming. Based on this new typology and regarding to the results of this study, it could be noticed that two kinds of fish farming are practiced in Burundi: (i) fish farming to consumption and (ii) artisanal fish farming "small" market production.

\subsection{Constraints Synthesis for Takeoff Fish Farming in Burundi}

Physical constraints (topographical and soil constraints): they vary according to localities. The rugged relief in some localities of the provinces studied (more than 1,000 $\mathrm{m}$ of altitude) does not allow ponds installing. For example, in Bujumbura province, $86 \%$ of fish farmers investigated confirmed that they have had many difficulties while digging ponds. Because of the rugged land, rainy waters are driven toward the pipes ponds with consequences as water pollution, invasion of predators and sometimes the escape by the overflow of water from ponds.

Edaphic constraints mentioned in the study are primarily related to the nature of the soil. Some soils are generally vertisols and ferrisols to weak capacity of water retention and which don't facilitate the ponds installation. In Cibitoke province, $71 \%$ of fish farmers 
investigated revealed that they have dug very difficultly ponds of their own strength and were forced to find elsewhere clay to reduce water loss by infiltration. The $29 \%$ of fish farmers investigated confirmed that they used the cheap labor.

Technical constraints: They were formulated by $80 \%$ to $100 \%$ of fish farmers investigated according to the provinces. There is generally for the entire province, only one coach (without means of transport and generally without sufficient technical baggage). As consequences, fish farmers have to grope concerning food, stocking and monitoring. As for calculation of income and profitability, it emerged from interviews with fish farmers that many of them did not have basic training to enable them to integrate all variables in the various calculations. The fish consumed is often not taken into account in computing income. They can sometimes wrongly assert that the activity is not profitable.

As mentioned above, the lack of nursery centers across the country brings fish farmers to resort to questionable quality fingerlings and uncertain productivity.

Lacking of center for the production of fish is compound foods (through the country). Thus, as mentioned above, over $95 \%$ of fish farmers throw in fish ponds only agricultural by-products (part of which is consumed and another for compost) without complete feed intake.

Materials constraints: The quasi-totality of fish farmers use rudimentary equipment and everybody ignore essential materials for fish farming such as sorting table, precision balance, packaging for transport fingerlings and fish in good conditions.

Financial constraints: Nearly $70 \%$ of Burundian live below the poverty line (less than one USD per day per inhabitant) and $85 \%$ of households routinely face food insecurity. In front of extreme poverty, it is difficult for people to set up a fish farm without financial support or the lack of micro-finance institution.

\subsection{Assets, Perspectives and Suggestions}

Assets: Burundi has a dense hydrographic network, a favorable climate and several sites favorable to the fish ponds installation. Water resources are generally abundant. The network of streams, rivers and swamps occupy about $10 \%$ of the total area, distributed between the 2 drainage basins (Congo and Nile basins). Indeed, Burundi has 943 swamps covering a total area of 117,993 hectares. About 81,403 hectares of them (68.99\% of the total area) are subject to agricultural exploitations without any special amenities. Only 6,567 hectares having made subject to amenities between 1990 and 1999, but they require a serious rehabilitation. Among all swamps area, 26,021 ha (22.5\% of total) didn't have any exploitation [1]. So, it is possible to make agricultural development. Beside these natural assets, the willingness of the population can be added especially one because of the isolation hardly enjoys the fish from lake of Tanganyika and the lakes of the north of the country. Indeed, $100 \%$ of investigated fish farmers confirmed to have the willingness to continue the activity as long as the essential constraints mentioned are lifted.

Perspectives: The relatively large potentialities in water resources (favorable to fish farming) available to Burundi constitute important assets. Rational exploitation and qualified framing could achieve a higher contribution to the current level and improve the availability of fish products and therefore, the incomes of producers. In view of the above mentioned advantages, the perspectives for fish farming are good if the constraints mentioned in this study are bypassed

Suggestions: In view of all the above, it is recommended to the government to institute a support fund for promotion of fish farming, to make available in each municipality a storehouse for selling essential equipment and nutrient inputs in sufficient quality and quantity. It is also important to affect in all municipalities the technicians trained in fish farming. These municipalities should be equipped by fish nursery center as well as a fish food transformation unity. 


\section{Conclusion}

The results of physical, chemical and ecological parameters showed that fish ponds are poorly maintained. It had been noticed that the fish farming in Burundi is suffering lack of nursery centers for the provision of food, materials and fish fingerlings in sufficient quantity and quality. To solve these problems, it could add insufficient technical supervision and poor functioning of associations. The main consequences are the low yields and the lack of enthusiasm for the fish farming in the country. In spite of these constraints, it was noticed that the majority of fish ponds were located in suitable sites (available water quantity and quality, favorable soil and climate). The fish species (Oreochromis niloticus) mainly elevated is perfectly adapted across the country except in some high altitude areas where temperatures varies between $15{ }^{\circ} \mathrm{C}$ and $20{ }^{\circ} \mathrm{C}$. The reorganization of the sector could permit it to contribute the Burundian food security.

\section{References}

[1] République Du Burundi. 2008. Stratégie Nationale Agricole (2008-2005). Burundi: Agriculture Et De Elevage.

[2] République Du Burundi and F.A.O.. 2009. Programme
National De Sécurité Alimentaire (PNSA) (2009-2015). Burundi: Agriculture Et De Elevage.

[3] République Du Burundi. 2008. Recensement Général De La Population Et De Habitat. Burundi: Ministère De Intérieur.

[4] Ntineshwa, S. 1990. Grossissement Du Tilapia Nilotica En Étang à La Station Piscicole De Mwisale. Bujumbura: Université Du Burundi.

[5] Bidou, J. E., Ndayirukiye, S., Ndayishimiye, J. P., and Sirven, P. 1991. Géographie Du Burundi. Paris: Paris HATIER.

[6] Assiah, V. E., Ton, V. S., and Aldin, H. 2004. La Pisciculture En Eau Douce à Petite Échelle. Wageningen: Fondation Agromisa.

[7] Coche, A. G., Muir, J. F., and Laughlin, T. 1997. Méthodes Simples Pour Laquaculture, Pisciculture Continentale: La Gestion, Les Etangs Et Leur Eau. Rome: F.A.O..

[8] Moreau, J. 1983. Etude Des Possibilités De Développement De La Pisciculture Intensive Au Burundi. France: Centre Technique Forestier Tropical.

[9] Vivier, P. 1972. La Pisciculture. 3ème Édition Mise à Jour. Paris: Presses Universitaires De France.

[10] Lacroix, E. 2004. Pisciculture En Zone Tropicale. Hamburg: GFA Terra Systems Eulenkrugstrae.

[11] F.A.O.. 1986. Lélevage Du Tilapia Nilotica. Manuel Pour Les Animateurs Piscicoles En RCA. Rome: F.A.O..

[12] Lazard, J., and Weigel, J. Y. 1996. "Laquaculture Des Tilapias En Afrique Francophone Subsaharienne: Bilan Et Perspectives.” In Le Troisième Symposium International Sur Le Tilapia En Aquaculture ICLARM Conf. Proc., 41. 